CIRJE-F-894

\title{
The Response of Asset Prices to Monetary Policy under Abenomics
}

Kazuo Ueda

University of Tokyo

July 2013

CIRJE Discussion Papers can be downloaded without charge from:

http://www.cirje.e.u-tokyo.ac.jp/research/03research02dp.html

Discussion Papers are a series of manuscripts in their draft form. They are not intended for circulation or distribution except as indicated by the author. For that reason Discussion Papers may not be reproduced or distributed without the written consent of the author. 
June 2013

\title{
The Response of Asset Prices to Monetary Policy under Abenomics*
}

\author{
Kazuo Ueda
}

\section{The University of Tokyo}

\begin{abstract}
Summary
In this paper I investigate the causes of the recent sharp response of the yen and Japanese stock prices to the discussion of, and the subsequent implementation of bold monetary easing by the Bank of Japan as demanded by Prime Minister Abe. I present statistical evidence that the response of the two asset prices have indeed been unusually large relative to the past experience with $\mathrm{NCM}$ even after allowance is given for the rise in global economic activity and asset prices. I also point out that the rally has been led by speculative trade by foreign investors while domestic investors have largely stayed on the sidelines. I discuss possible backgrounds for such foreign investor behavior. Simply put, the unprecedented political pressure raised hopes of the adoption of bold measures by the Bank. I discuss, however, the possibility that the room for further action by the Bank is quite limited apart from what might be called a targeted helicopter drop of money. I also point out the possibility that investor behavior has not been based on economic fundamentals. The asset price volatility since April 2013 is interpreted in the light of such discussions.
\end{abstract}

*The author would like to thank Kazumasa Iwata, Kosuke Aoki and the editors of the journal for helpful comments on an earlier version of the paper. Financial assistance from CARF at the University of Tokyo is gratefully acknowledged. 
In late 2012 Shinzo Abe, then the President of Japan's Liberal Democratic Party, started to place unprecedentedly strong pressure on the Bank of Japan (BOJ) to ease monetary policy aggressively. The Bank would lose independence, he argued, unless it complied. The BOJ responded in early April 2013 by announcing "quantitative and qualitative easing (QQE)," which involved huge purchases of long-dated Japanese government bonds (JGBs) and ETFs, and a promise to increase base money by $100 \%$ in an attempt to hit a $2 \%$ inflation target in two years. Such a chain of events regarding monetary policy has created surprising movements in asset prices. Between mid-November 2012 and mid-May 2013 the yen weakened by $25 \%$ and Nikkei 225 rose by $80 \%$. Since then, both markets have seen a substantial correction.

Such a response of asset prices has been surprising because they hardly responded to easing measures adopted by the BOJ during years 2010-2012, which involved purchases of the same set of assets, although the size of purchases was not as large as in the most recent package. More broadly, central banks in developed economies have doubled or tripled their balance sheets since the economic and financial crisis of the late 2000s. Nominal GDP of these economies have shown almost no correlation with such movements in base money.

In this paper I discuss the backgrounds for large asset price movements in Japan during the last few months. The discussion emphasizes two noteworthy features of the current episode. One is the enormous political pressure placed on the BOJ. Huge political pressure on a central bank has always been a necessary condition for a high rate of inflation. I discuss whether such a consideration is important in the current Japanese context.

The other feature of the asset price response has been the contrasting response of foreign and domestic investors. Foreign investors, especially the fast money community, have sold the yen and bought Japanese equities on a large scale, while the domestics have largely stayed on the sidelines. The behavior of foreign investors seems to have been based on the view that aggressive use of NCM, even if it does not lead to improvements in the real side of the economy, is capable of raising asset prices. The view must have been based on investors' experience with the easing carried out by global central banks, especially the Fed and the ECB. 
I argue that the view contains an element of irrationality. It does not seem to distinguish between different types of NCM properly. Thus, investors may have shown a sunspot type response to the prospect of, and the actual large BOJ easing without a deep understanding of the workings of NCM.

In order to establish these points I devote the first half of the paper to the discussion of the past experience of central banks with NCM, especially, that of the BOJ. I start by offering a typology of NCM that includes a brief discussion of the theoretical rationale for each measure as well. I then carry out a simple regression analysis of the effectiveness of the Fed's and the BOJ's NCM in an attempt to show that the asset market response during the last few months in Japan was surprising in light of earlier experiences. I also present some evidence of irrationality of investors.

Based on such a technical analysis, I offer, in the second half of the paper, some informal discussion about why asset prices have responded in the way summarized above to the political pressure on the BOJ, and the actual implementation of NCM. The discussion first emphasizes the contrast between foreign and domestic investors. I then proceed to the backgrounds for speculative trades carried out by foreign investors and offer several explanations including the possible irrationality of investors. I also interpret the volatility seen in all markets since the inception of QQE in the light of such explanations. The paper's discussion is mostly confined to the relationship between asset prices and NCM. The relationship between the real economy and NCM will be only briefly discussed.

\section{1, A Typology of Nonconventional Monetary Policy Measures}

Let me start by defining the terminology used throughout the paper and at the same time offer a brief summary of theoretical arguments for and against the effectiveness of NCM. ${ }^{2}$ NCM central banks have adopted can be classified into "large scale asset purchases", "quantitative easing" and "forward guidance of interest rates and or future asset purchases." Large scale asset purchases, in turn, consist of those in distressed markets and in more normal markets. The term "large-scale asset purchases" is usually used when the central bank is concerned with what type of assets it purchases, while "quantitative easing" is used when the bank is more

\footnotetext{
2 This section draws heavily on Ueda (2012c). See also Bernanke (2012) and Woodford (2012).
} 
concerned with the size of its balance sheet. Large scale asset purchases have in many cases been accompanied by quantitative easing, but not always.

Large-scale asset purchases have occurred in many forms. The theoretical rationale for such actions seems to rest on the existence of market imperfections. During a financial crisis, a sharp decline in investors' ability to take risks reduces market liquidity in certain segments of the financial system. In such markets, central bank purchases of assets can lower liquidity/risk premiums and in this way support the economy (Type 1 Large Scale Asset Purchases: LSAP1). Allen and Gale (2007), Curdia and Woodford (2010), Gertler and Karadi (2012) discuss the usefulness of such operations, which are sometimes called "credit easing." In addition to security markets, interbank markets can become dysfunctional due to heightened counterparty risks, especially in term markets. In such a case central banks can make term loans in order to contain risk premiums. Such operations may also be regarded as credit easing.

Other types of large-scale asset purchases by central banks are purchases of Treasury bonds or private financial instruments in more normal conditions (Type 2 Large Scale Asset Purchases: LSAP2). For example, many central banks have purchased long-term government bonds and expanded their balance sheets. Such an operation can be decomposed into pure quantitative easing (to be defined below) and a so-called "operations twist," which is a form of LSAP2, involving the central bank purchases of long-term Treasury bonds while at the same time selling short-term Treasury bills. Thus, LSAP 2 may or may not be accompanied by pure quantitative easing. The operations twist part of the measure affects the yield curve if investors in such securities are segmented or have "preferred habitats." The effects could spill over into other markets such as the corporate bond market through portfolio rebalancing effects. Whether such "market imperfections" exist has long been debated. It seems fair to say, however, that no consensus has emerged yet.

Some have argued that irrespective of what a central bank buys, an expansion of the central bank balance sheet generates an easing effect by itself. An example would be central bank purchases of Treasury bills, a plain vanilla instrument, in order to supply liquidity beyond the level required for a zero percent policy rate. In the following let me call such 
attempts "pure quantitative easing (QE0)" in order to distinguish them from quantitative easing that accompanies large scale asset purchases. At a zero interest rate, however, the economy is largely satiated with liquidity. Hence, it is not clear why attempts to add still more liquidity will produce any significant results. Of course, it would be a different story if the central bank was financing government purchases of goods and services-a helicopter drop of money.

An entirely different form of unconventional monetary easing is forward guidance - providing assurance to the market that the key policy interest rate, like the call market rate, will be lower in the future than currently expected. To affect market expectations of future short rates, the central bank needs to commit to monetary easing even after the economy no longer requires it. This promise of unnecessary future easing creates an expectation of rising inflation. ${ }^{3}$ If real interest rates decline, easing effects are generated. A serious problem with the forward guidance strategy is that it is not time consistent, that is, there is an incentive on the part of the central bank to renege on its promise once inflation comes back to normal levels.

In addition to the caveats mentioned, the underlying logic of how NCM measures work suggests certain limits on what they can be expected to achieve. LSAP1 - that is, operations in temporarily dysfunctional markets - should come to an end once the markets are normalized. Forward guidance of interest rates is an attempt to narrow long-short interest rate spreads up to a certain maturity. LSAP2, asset purchases in more normal markets, may reduce risk premiums. But there are likely to be limits to the extent of the fall in interest rate spreads or risk premiums. Also, as the size of such operations becomes very large, one has to start worrying about distortions generated by direct central bank involvement in financial intermediation.

Table 1 illustrates some of the typical nonconventional measures adopted by the BOJ, the Fed and the ECB. Detailed explanation of these

\footnotetext{
${ }^{3}$ Bauer (2012) argues that large-scale asset purchases or QE0, by sending the signal that the central bank will continue to be aggressive in monetary easing in the future, also entail an element of forward guidance-a signaling effect. What is important, however, is not the amount of today's balance sheet expansion, but a promise of its continuation into the future. And, the effectiveness of that policy stems from that of forward guidance.
} 
measures can be found in Ueda (2012a, b). Let me here point out that the central banks employed LSAP1 extensively during the acute phase of financial crises, that is, during the late 1990s to early 2000s in Japan and 2008-09 in all three areas. The ECB, with its problems in the government bond market of Southern European countries, is still relying heavily on LSAP1. As financial stresses abated, the BOJ and the Fed have turned to the use of LSAP2 measures. Forward guidance was first used by the BOJ in 1999 and subsequently by the Fed in 2003. Both central banks have used the strategy in various forms since then. QE0 has been tried by only the BOJ. The BOJ has also embarked on extreme measures such as purchases of equities. Let us now turn to the analysis of the effectiveness of such measures.

\section{2, Statistical Evidence on the Effectiveness of NCM under Abenomics}

In this section I offer some statistical evidence on the impact of monetary policy under Abenomics on asset prices. The analysis builds on Ueda (2012b), which carries out an event analysis of the effectiveness of the BOJ's NCM using daily data on asset prices. In this paper, I will mainly rely on the analysis of monthly data. This is because I would like to check if monetary policy measures are significant even after inclusion of variables on the real side of the economy, which are available only at the monthly frequency. Also, a finding that policy measures affected asset prices only for a day or two seems of little practical relevance. ${ }^{4}$

As a preliminary check, I repeated the daily data analysis of Ueda (2012b) to include the data up to the end of April 2013. Thus, Japanese asset prices were regressed on monetary policy dummies and U.S. asset prices. The monetary policy dummies included, in addition to the ones used in Ueda (2012b), all the dates of monetary policy change announcements since then and two others, one, November 16, 2012 when Japan's lower house was resolved and, the other, December 16, 2012 when the LDP won in the election. These two dates are significant because the probability of the adoption of the kinds of monetary policy measures Shinzo Abe was

\footnotetext{
${ }^{4}$ Of course, the downside of using monthly data as opposed to daily data is the possibility that policy dummies pick up the effects of other news. Thus, in the following I refer to the results of the analysis that uses the daily data as well.
} 
advocating must have risen on these dates. Let me note that there are two more dummies for the period since November 2012. One for January 22, 2013 when the BOJ agreed to a $2 \%$ inflation target and, the other, April 4, 2013 when QQE was announced. The dependent variables are the rate of change in TOPIX, the yen/dollar rate and the first difference in the 10 year JGB rate. In addition to the policy dummies, the call market rate, the S\&P 500, 10 year US Treasury yield and the Euro/dollar rate were included as independent variables.

Not surprisingly, the pattern of the significance of the monetary policy dummies is almost the same as in Ueda (2012b) and is not repeated here. Some, but not very many, of the LSAP2 measures in 2011 are significant. Among the dummies from the Abenomics period, the April 4, 2013 dummy is significant in all equations. In addition, November 16, 2012 is significant in the exchange rate equation. Given the large movements in asset prices during this period, it is somewhat surprising that the other dummies are insignificant.

Turning to monthly data, I include in the regressions, in addition to the independent variables mentioned, the Shoko Chukin business sentiment index, the JP Morgan Global Purchasing Managers Index for Manufacturing and the number of initial unemployment claims in the U.S. These variables are considered to be good coincident indicators of economic activity in the market. I assume that these as well as foreign asset prices are exogenous variables in the equations estimated. It was not possible to include all the monetary policy dummies due to the degrees of freedom problem. However, all those dummies that turned out significant in the daily data equations were at least included. Also, given the focus of the paper, all the four dummies during the Abenomics period were included. The estimation period is April 1998, right after the BOJ was made more independent, through April 2013.

Table 2 shows the estimation results. The first column identifies the monetary policy measures. The second column shows categorization based on the typology of the last section. The shaded cells in the remaining columns indicate the significance of corresponding monetary policy dummies at least at the $90 \%$ level. Each policy dummy is assumed to take the value of one in the month when the measure is introduced.

The results are not very different from Ueda (2012b). Thus, the 
forward guidance measures affected the interest rate or the exchange rate. The introduction of QE in March 2001 affected both the stock price index and the exchange rate. However, increases in the current account balance target in the early to mid-2000s had almost no effects on asset prices. This is true especially for those that were not accompanied by increased purchases of JGBs, that is, QE0 type measures.. Two of the LSAP1 measures during 2008-09 had some effects on asset prices. None of the LSAP2 measures during 2010-2011 are significant. ${ }^{8}$

A noteworthy result of the table is the significance of the dummies after 2012. The February 2012 announcement to carry out monetary policy more aggressively affected the yen and TOPIX. Three of the four dummies during the Abenomics period exerted some effects on either the yen or TOPIX. The result is important because the regressions control for improvements in global economic conditions and investor sentiments during the period. Coefficient estimates indicate that the February 2012 announcement explains $106 \%$ of the change in the yen and $77 \%$ of the change in TOPIX, while the Abe dummies all combined, $83 \%$ of the exchange rate change and $45 \%$ of the rise in TOPIX.

The significance of 2012 and 2013 dummies is surprising. Monetary policy measures adopted during this period are essentially LSAP2 type ones. LSAP2 measures during 2010-11, however, are insignificant as well as most of those adopted by the Fed as we will see shortly. Although QQE included a promise to expand base money, the effectiveness of such QE0 type measures is, as we have seen, very questionable both theoretically and empirically. What is special about this period? A detailed discussion of this question is relegated to the next section. But let me offer some preliminary considerations here.

First, on February 14, 2012 and January 22, 2013 the BOJ strengthened its commitment to inflation target. These dates are, however, insignificant in the daily data regressions. Also, a statement of a target per se does not seem to change people's expectations unless it is accompanied

\footnotetext{
${ }^{8}$ In addition, the May 2003 dummy was significant in the TOPIX equation, but was also significant with a wrong sign in the interest rate equation. With high likelihood, the dummy is picking up the effects of the government's decision on May 17, 2003 to de facto nationalize Risona Bank. In fact, use of daily data revealed no such significant effects of the dummy . Thus, I have decided not to mark the corresponding cells in Table 2.
} 
by effective measures to achieve the target. In fact, given the absence of such measures, the rally in the dollar/yen and stock prices in the spring of 2012 quickly faded away.

A second possible cause of the reaction in the market is the presence of strong political pressure on the BOJ to ease. This is evident for the Abenomics period. Also, strong pressure from the Noda administration was a proximate cause of the February 2013 easing. The implication of such political pressure for the effectiveness of monetary policy will be discussed in the next section.

At this point it would be appropriate to discuss the discrepancy between the results of daily and monthly data regressions. The results agree on the significance of the April 4 easing. Apart from this, however, only the November dummy in the TOPIX equation is significant in the daily data results (Table 2A), while with monthly data the same dummy is insignificant but the two other dummies are significant at least in one of the equations.

The discrepancy in the results seems to be indicative of an important characteristic of asset price movements during November 2012-March 2013; that is, the near absence of large daily changes in asset prices. Small daily moves in the yen and stock prices culminated in large changes. Therefore, the daily data regressions do not pick up many significant effects of the dummies, while the monthly dummies do. Such a pattern of movements in asset prices do not conform to a simple efficient market theory type view whereby arrivals of important news generate jumps in asset prices. Instead, investors one after another were slowly lured into the market as they observed asset prices continuing to move in one direction. However, given the apparent absence of other important events and the fact that I am controlling for the effects of other economic variables, the significance of December 2012 and January 2013 dummies in the monthly data regressions may be ascribed to the slow response of investors to the prospect of aggressive monetary easing.

\section{The Soros Chart}

Before turning to the discussion of the significance of Abe dummies, I present some applications of the regression analysis reported above to questions relevant for considering the effectiveness of NCM. First, the 
regression framework easily lends itself to a test of the validity of the so-called Soros Chart, i.e., the relationship between the exchange rate and relative money supplies. The relationship is an empirical one entertained among some investors, especially, in the foreign exchange market. The analysis of the relationship serves as a further test of the effectiveness of QE0 type monetary policy measures.

The first row of Table 3 shows the same exchange rate equation as in Table 2 with the US-Japan relative base money term included, but with the effects of the monetary policy dummies suppressed for the sake of brevity. The relative base money term is significant with the right sign. Thus, an expansion of base money relative to that of the foreign economy seems to stimulate the economy by generating a weaker currency. The second row of the table, however, breaks relative base money into Japanese and U.S. base money. It shows that what matters is only U.S. base money.

Figure 1, the scattered diagram of the rate of change in the exchange rate and US base money, shows what is going on very clearly. The positive correlation between the yen-dollar rate and US base money relies on just a handful of observations from late 2008 and early 2009, that is the period right after the failure of Lehman Brothers. Table 3, in rows three and four, shows that once six observations are excluded from this period neither relative base money nor US base money is significant.

The period in question was when investors dumped the U.S. dollar at the outbreak of the serious financial crisis in the U.S., while the Fed supplied liquidity massively in order to contain the serious stresses in the financial system. The U.S. monetary base more than doubled between August 2008 and April 2009. The increase, however, was clearly due to various LSAP1 measures. The exchange rate and U.S. monetary policy were responding to a third variable, that is, the outbreak of a financial crisis. The Soros equation is getting the causality wrong. Such an analysis seems to cast a serious doubt as to some investors' ability to distinguish between different types of NCM.

\section{The Effectiveness of the Fed's NCM}

Next, Table 4 presents a similar set of regression results for the Fed. The dependent variables are the 10 year US Treasury yield, S\&P 500 and the Euro-Dollar exchange rate. As independent variables, I include the 
federal funds rate, the number of initial unemployment claims, JP Morgan global manufacturing PMI and the spread between German and Spanish 10 year government bond yields. The European bond yield spread is meant to capture the effects of the Euro crisis on the US asset prices. ${ }^{11}$ The variables are monthly changes. The policy dummies are assumed to be of one month duration as in the Japanese case. One exception is the QE2 dummy for which the value of one is assigned from August 2010 to November 2010 in view of the early references to the measure by the Federal Reserve Chairman Bernanke. ${ }^{12}$ The period of estimation is from June 2007, right before the outbreak of the financial crisis, to April 2013.

The table shows that only a few of the Fed's policy measures exerted significant effects on the asset prices. The LSAP1 type measures, that is, the Fed's QE1 measures adopted during late 2008 to early 2010 had the effect of lowering the long-term interest rate, raising stock prices and, the December 2008 measure, weakening the dollar. ${ }^{13}$ The strengthening of forward guidance in August 2011 lowered the interest rate. ${ }^{14}$ None of the other measures, however, had any significant effect on asset prices

Thus, despite the perception in the market that the Fed's NCM measures, especially LSAP2 type measures, have had powerful effects on asset prices, Table 4 does not quite support such a view. It is also interesting to note that the size of the effect of NCM measures on the interest rate declines as we move from the first row of the table to the fourth row. The market could be erroneously attributing the effects on asset prices of improvements in the economy or forward guidance to those of LSAP2. For example, the S\&P 500 index rose significantly around the time of the introduction of QE2. The regression result indicates that this rise in stock prices is mostly explained by an improvement in the economy, that is, declines in initial unemployment claims. The result is consistent with what

\footnotetext{
11 The German-Spanish spread was insignificant in any of the Japanese asset price equations. The variable seems to have affected Japanese asset prices through global asset prices.

12 The results, however, were little changed with alternative assumptions about the length of the QE2 dummy.

13 In light of the above analysis of the Soros equation, this dummy may well be picking up the effect of the financial crisis not adequately captured by the German-Spanish interest rate spread rather than monetary policy in the exchange rate equation.

14 Woodford (2012) and Swanson \& Williams (2012) also report findings of significant effects of this policy measure on interest rates.
} 
I found earlier with weekly data for the U.S. (See Ueda (2012b).)

\section{4, The significance of the Abe dummies}

The anatomy of Abe -trade

We have demonstrated that the currency and stock markets responded significantly to the prime minister's pressure on the BOJ to ease policy and to subsequent monetary easing, which were mostly LSAP2 type measures. And, this is in sharp contrast to the failure of LSAP2 to significantly affect asset prices in either Japan or the U.S. Before discussing why this was so, let us look more carefully at the characteristics of trading in the asset market during this period (Abe-trade).

The most noteworthy feature has been the dominance of foreign investors in the currency and stock markets. Since official data is available only for the stock market, I show in Figure 2 the net purchases of Japanese equities by type of players. As can be seen, only foreigners have been buying equities consistently since November 2012. Similar anecdotal stories abound regarding yen short trade. Thus, Japanese players have mostly stayed on the sidelines in these markets.

In contrast, the JGB market has been dominated by domestic financial institutions who had not, until early in April 2013, sold the bonds in response to either the talk of Abenomics or changes in asset prices in the other two markets. Thus, JGB yields moved in small ranges and then moved lower in March in anticipation of increased JGB purchases by the BOJ.

Thus, there has been a clear decoupling of domestic investor behavior from that of foreign investors. The absence of an upward tendency for interest rates may have made larger the rally in the yen/dollar and Japanese equities.

The picture has changed slightly since the announcement of the monetary policy package on April 4. QQE raised the volatility and levels of JGB yields significantly. The 10 year JGB rate moved from a low of $0.32 \%$ on April 5 to a high of $.97 \%$ on May 23. With the rise in interest rates, the stock market saw a sharp correction exceeding $20 \%$ by early June. The yen went up by almost $10 \%$. Both asset prices roughly were back at levels when QQE was announced, erasing the gains since then.

The limited participation of domestic investors in the Abe trade 
means that there has not been much of portfolio rebalancing trade taking place. Even with heavy selling of JGBs since April, domestic investors have not bought equities or foreign assets on an unhedged basis on a large scale.

\section{Factors behind the Foreign Investor Behavior}

The asset price behavior during the last six months was thus mainly driven by speculative trade of foreign investors who formed high expectations regarding the possibility of, and effectiveness of, aggressive monetary easing by the BOJ. The major factor behind this seems to have been the huge political pressure placed on the BOJ to ease aggressively by the prime minister, as pointed out in the previous section in relation to the regression results. The reasoning of foreign investors seems to have been very simple. Aggressive application of NCM would generate asset price inflation if not goods price inflation. The BOJ had not been aggressive enough. The behavior of the BOJ, however, would change under significant political pressure.

In the following I provide an evaluation of such a line of thinking on several fronts. I first discuss some of the problems of the BOJ's NCM during the last 15 years. I then speculate whether there is any traction left of NCM at this juncture. I next turn to the discussion of possible irrationality in the behavior of foreign investors. Finally, I wrap up in the concluding section by discussing the asset price volatility since April 2013.

\section{Critical Evaluation of the BOJ's NCM}

There is some truth to the argument that the BOJ has not done enough to end deflation. I point out two most noteworthy ones. First, two premature exits from the forward guidance strategy hurt its reputation; one in August 2000 and, the other, in March 2006. In both cases the (ex energy \&food) component of CPI was still falling at the time of exit despite the promise of the continuation of a zero rate until "deflationary concerns were dispelled," or "inflation was stably above zero." Such decisions seem to have generated investors' doubts about the BOJ's resolve to fight deflation and weakened the power of subsequent NCM to stimulate the economy.

In late year 2000, after the rate hike in August, the BOJ internally held a series of meetings to discuss the appropriate "target" rate of inflation. 
The meetings did not result in a clear cut target because one group argued for a small positive inflation rate while another for a zero inflation rate (BOJ (2000)). The rate hike decision in August could not have been justifiable if the target was a positive rate.

Another problem with the BOJ's NCM may have been its reluctance to buy JGBs on a large scale. Thus, in early years of NCM, 1998-2000, the BOJ did not increase its monthly purchases at all. The amount of purchases was increased during 2001-03, but not afterwards until 2008. The BOJ's LSAP2 program, CMP, had placed restrictions on the duration of JGBs the Bank purchases under the program. All this stemmed from the Bank's determination "not to underwrite the government's budget deficits," but may have weakened the effectiveness of the Bank's purchases of JGBs by limiting the duration risk the Bank was taking.

\section{Availability of Further NCM Measures}

Are there then measures left for the BOJ to stimulate the economy effectively? One answer to this has been the BOJ's QQE announced in April. It consists of QE0, base money targeting, and LSAP2, purchases of mainly JGBs and ETFs. The QE0 part of the package is not very impressive given the theoretical and empirical arguments so far. The purchases of JGBs, however, have addressed the point made above. The BOJ has announced that it would increase the average duration of JGBs from 3 years to 7 years. Also, the amount of purchases is very large. The BOJ's holdings of JGBs are expected to roughly double in two years.

It is, however, unclear whether such JGB purchases will exert strong effects on the economy. In order to generate portfolio rebalancing effects the purchases need to lower interest rates, or they need to contain the rise of nominal interest rates so that real interest rates decrease as inflation expectations increase. The 10 year JGB rate, however, was already at around $0.6 \%$. It was unclear by how much rates could decline further and, even if they did, to what extent rate declines would stimulate the economy. In the event interest rates have not declined since April, and large portfolio rebalancing effects have not been observed yet.

What about other possibilities? History shows that strong political pressure on the central bank to ease sometimes lead to significant inflation. One can simply imagine a central bank that is forced to underwrite the 
government's budget deficits. This possibility is relevant for Japan due to her critical fiscal situation. Also, the Abe administration passed a supplementary budget amounting to 13 trillion yen in early 2013. The administration, however, does not seem to be prepared to continue easing fiscal policy. It has shown some respect for the need for long-term fiscal consolidation as well. In fact, Abe has explicitly stated that achieving a $2 \%$ inflation target is the responsibility of the BOJ.

Can the BOJ carry out policy measures that are essentially fiscal expansion and finance them by herself? The answer seems to be a provisional yes. LSAP2 measures may be used to raise asset prices, providing wealth effects to the holders of the assets (a targeted helicopter drop of money). For example, the BOJ might keep on buying equities in an attempt to support equity prices. The scope of such actions, however, can be limited by the controllability of asset prices. The size and duration of the operations need to be very large to generate meaningful effects on the economy. Any central bank would hesitate to carry out such operations given the risk to its balance sheet they entail. The damage to the functioning of the market can also be substantial. It would be different, however, if the central bank is forced into action by the government. Such possibilities may have been priced in by foreign investors.

\section{Irrational Elements in Foreign Investor Behavior}

Another explanation of the large response of asset prices is the possibility that foreign investors have had an (overly) optimistic view about the effects of NCM, especially when measures are adopted on a large scale. The discussion of the characteristics of Abe-trade already showed that foreign investors have been more optimistic than domestic investors on this point. It is easy to see that the more pessimistic view of domestic investors can be attributed to the failure of monetary policy to stop deflation during the last 15 years.

The optimism of foreign investors must have come from the experience of NCM adopted by the Fed and to some extent by the ECB. In both the U.S. and Europe asset prices rebounded from the sharp declines seen around the Lehman event thanks at least partly to NCM measures adopted. Investors also think that high levels of U.S. stock and bond prices since 2010 are at least partially attributable to monetary policy. 
A non-negligible portion of such optimism about the effects of NCM on asset prices, however, seems to be based on confusion about how NCM works. For example, there is a popular view that movements in relative base money are a major determinant of the exchange rate. One application of this is that less aggressive monetary expansion by the BOJ than that of the Fed during 2008-09 produced a sharp yen appreciation. As I argued in section 2, a more reasonable interpretation is that the serious U.S. financial crisis at the time (initially) weakened the dollar sharply on the one hand, and, on the other, forced the Fed to carry out LSAP1 on an unprecedented scale. Thus, the causation was not from monetary policy to the exchange rate. The BOJ had to do less of LSAP1 given that Japan was not the epicenter of the crisis. As I showed, the proposed relationship between relative base money and the exchange rate disappears once observations from this period are excluded.

In the summer of 2012, the ECB president Drahgi made the famous remark that "the Bank will do whatever it takes to defend the Euro," and announced the OMT program to stabilize European government bond market. This has had a remarkable impact of stabilizing the market despite no activation yet of the program so far. The success of the ECB intensified the feeling among investors that the BOJ should do "whatever it takes to stop deflation" and would succeed if the Bank were bold enough. The problems two banks are addressing, however, are entirely different. Europe's problem is government bond market in distress. Thus, the ECB has been employing LSAP1 measures, which are in many cases effective. The BOJ, faced with deflation, will have to use LSAP2, forward guidance and possibly other measures, whose effectiveness is unclear. The market is again not seeing essential differences between different types of NCM.

Results in Table 4 showed that with the exception of the forward guidance in August 2011, recent measures adopted by the Fed have not exerted significant effects on asset prices. Yet, the view that LSAP2 measures exert strong effects on asset prices seems to prevail.

Thus, there is a distinct possibility that the foreign investor response has been based on "irrational exuberance" that turned on the adoption of aggressive NCM. If resulting asset price inflation happened to stimulate the economy, however, it would be like a sunspot behavior in multiple equilibrium models, with NCM playing the role of sunspots. Of course, in 
order to show that multiple equilibriums are indeed possible we need a model of the real sector of the economy, which is beyond the scope of this paper. ${ }^{18}$ Alternatively, the slow but steady exchange rate and stock price movements during November 2012-March 2013, which we pointed out in section 2, may suggest a "beauty contest" type asset price determination as in Keynes' General Theory. Any of these non-fundamentals based interpretations of the recent asset price inflation suggests that asset prices may decline suddenly in response to an abrupt change in investor psychology.

\section{4, The Asset Price Volatility since April 2013 and Concluding Remarks}

In this paper I have investigated the causes of the recent sharp response of the yen and Japanese stock prices to the discussion of, and the subsequent implementation of bold monetary easing by the BOJ as demanded by Prime Minister Abe. I have shown statistically that the response of the two asset prices have indeed been unusually large relative to the past experience with NCM even after allowance is given for the rise in global economic activity and asset prices. On close inspection I find that the rally has been led by speculative trade by foreign investors while domestic investors have largely stayed on the sidelines. I have discussed some possible backgrounds for such foreign investor behavior. There have certainly been hopes for bold action by the BOJ. It is unclear, however, if significant measures are remaining after 15 years of repeated dose of NCM. I have pointed out the possibility of targeted helicopter money using, for example, equity purchases by the BOJ. Another explanation of investor response is that it has not been based on economic fundamentals. For example, it may have been a sunspot type reaction to NCM.

What does the volatility in markets since April 2013 tell us about the plausibility of such alternative explanations of investor behavior? Surely, one straightforward interpretation is a sudden reversal of a non-fundamentals based asset price inflation triggered by, say, the volatility in the JGB market.

18 An example that builds on the Japanese experience with liquidity trap is Benhabib, Schmitt-Grohe and Uribe (2011). There is also a possibility that incorrect understanding of the workings of NCM becomes self-confirming as investor behavior, even if it is incorrect, affects asset prices and the economy. See, for example, Sargent (1999). I owe this literature to Kosuke Aoki. 
The second possibility, which is not inconsistent with the first, is that the traction left of JGB purchases is indeed very small. As argued in previous sections, interest rates are already very low and don't have a large room left to decline further, which then means only small rebalancing effects. Without rebalancing effects, one could argue, the rise in the stock market and yen weakness should not have taken place.

The third possibility is that QQE contains some strategic problems. It paid insufficient attention to the need to keep the levels and volatility of long-term interest rates low. The BOJ has promised to purchase JGBs massively, two thirds of new issuance, which has lowered the liquidity of the JGB market and raised volatility. By switching to base money targeting, the BOJ naturally allowed larger movements in interest rates. By declaring to hit the $2 \%$ inflation target in two years, the BOJ effectively shortened the expected duration of a zero rate, reversing the forward guidance policy it had been carrying out. The resultant upward pressure on the levels and volatility of interest rates may have prevented portfolio rebalancing effects from taking place. This is in contrast to the recent Fed's strategy, up until the spring of this year, to use forward guidance and asset purchases carefully to avoid a sharp increase in interest rates.

In any case it is too early to tell what explanation is the most plausible. Even though the asset markets have seen sharp corrections, they are still at levels that could generate non-negligible positive effects on the economy. Thus, the economy could move from bad to good equilibrium as in sun-spot theory. Or, the BOJ may succeed in stimulating the economy by further doses of NCM such as a targeted helicopter drop of money. 


\section{References}

Allen, F., and D. Gale. 2007. Understanding Financial Crises. Clarendon

Lectures in Finance. Oxford: Oxford University Press.

Bank of Japan. 2000. "On Price Stability.”

http://www.boj.or.jp/en/announcements/release_2000/k001013a.htm/

Bauer, Michel D. 2012. "Fed Asset Buying and Private Borrowing Rates." Economic Letters, Federal Reserve Bank of San Francisco, May 21.

Benhabib, J., S. Schmitt-Grohe and M. Uribe. (2001) "The Perils of Taylor Rules," Journal of Economic Theory 96, 40-69.

Bernanke, Ben S. 2012. "Monetary Policy since the Onset of the Crisis." May 31, http://www.federalreserve.gov/newsevents/speeches/bernanke20120831a.htm.

Curdia, Vasco, and Michael Woodford. 2010. "The Central-Bank Balance Sheet as an Instrument of Monetary Policy.” NBER Working Paper 16208.

Gertler, Mark, and Peter Karadi. 2012. “QE1 vs. 2 vs. 3 . . A Framework for Analyzing Large Scale Asset Purchases as a Monetary Policy Tool.” Paper presented at the Federal Reserve Board conference on "Central Banking: Before, During, and After the Crisis," March 23-24, 2012, Washington D.C. http://www.federalreserve.gov/newsevents/conferences/GertlerKaradi.pdf.

Sargent, T. 1999. The Conquest of American Inflation. Princeton University Press, Princeton, New Jersey.

Swanson, E. T. \& J. C. Williams. 2012. "Measuring the Effect of the Zero Lower Bound on Medium- and Longer-Term Interest Rates," Working Paper Series 2012-02. Federal Reserve Bank of San Francisco, May.

Ueda, K. 2012a. “Japan's Deflation and the Bank of Japan's Experience with Non-traditional Monetary Policy.” Journal of Money, Credit and Banking, 44(2): 175190.

Ueda, K. 2012b. "The Effectiveness of Non-traditional Monetary Policy Measures: The Case of the Bank of Japan." Japanese Economic Review 63(1):1-22.

Ueda, K. 2012c. "Deleveraging and Monetary Policy: Japan since the 1990s and the United States since 2007," Journal of Economic Perspectives, 26(3): 177-202.

Woodford. M. 1999. "Commentary: How Should Monetary Policy be Conducted in an Era of Price Stability?" Remarks at the 1999 symposium of the Federal Reserve Bank of Kansas City, Jackson Hole, Wyoming.

Woodford. M. 2012."Accommodation at the Zero Lower Bound," paper presented at the 2013 symposium of the Federal Reserve Bank of Kansas City, Jackson Hole, Wyoming. 
Table 1 Examples of Non-traditional Policies

\begin{tabular}{|l|l|}
\hline Forward guidance & $\begin{array}{l}\text { "A zero rate until deflationary concerns are dispelled" (BOJ: April 1999-August 2000) } \\
\text { "the committee expects that a highly accommodative stance of monetary policy will remain appropriate } \\
\text { for a considerable time after the economy strengthens." (Fed: September 2012) }\end{array}$ \\
\hline LSAP1 & $\begin{array}{l}\text { purchases of covered bonds, fixed rate full allotment operation,LTRO, OMT (ECB) } \\
\text { purchases of CPs, equities (2002-04), term fund provision (BOJ) } \\
\text { purchases of Agency bonds, Agency MBS, Treasuries (Fed: 2008-09) } \\
\text { TALF:lending against securitized assets (Fed:2009) } \\
\text { US dollar repo (major central banks) }\end{array}$ \\
\hline LSAP2 & $\begin{array}{l}\text { purchases of government bonds (2001-06), CME (2010-2012), QQE(2013-) (BOJ) } \\
\text { purchases of Treasuries, Agency MBS, operations twist (Fed: 2010-) }\end{array}$ \\
\hline QE0 & current account balance targeting (BOJ:2001-06), base money targeting (BOJ:2013-) \\
\hline
\end{tabular}

Table 2: Regression Results on the Effectiveness of the BOJ's Policy Measures

\begin{tabular}{|c|c|c|c|c|c|}
\hline & Category & & TOPIX & JGB 10yr & Yen/dollar \\
\hline ZIRP & F.G. & 1999.4. & & & \\
\hline Quantitative Easing & F.G./LSAP1,2 & 2001.3. & & & \\
\hline increases in the current account balances & & 2001.8. & & & \\
\hline \multirow[t]{2}{*}{ with increases in JGB purchases } & & 2001.12. & & & \\
\hline & & $2002 . .2$ & & & \\
\hline & & $2002 \underline{2} .10$. & & & \\
\hline Increases in the Current Account balances & QE0 & 2003.4 & & & \\
\hline \multirow[t]{3}{*}{ without increases in JGB purchases } & & 2003.5. & & & \\
\hline & & 2003.10. & & & \\
\hline & & 2004.1. & & & \\
\hline Yen/Dollar Swap & LSAP1 & 2008.9 & & & \\
\hline Facilitation of Corporate Finance,JGB Purchases & LSAP1 & 2008.12. & & & \\
\hline JGB purchase increased & LSAP1 & 2009.3. & & & \\
\hline Clarifying price stability, 3M Fixed Rate Ope. & F.G./LSAP1 & 2009.12. & & & \\
\hline CMP introduced & LSAP2 & 2010.10 & & & \\
\hline CMP expanded & LSAP2 & 2011.8 & & & \\
\hline CMP expanded & LSAP2 & 2011.10 & & & \\
\hline Further easing & LSAP2 & 2012.2 & & & \\
\hline Upper House Dissolved & & 2012.11 & & & \\
\hline LDP victory & & 2012.12 & & & \\
\hline $2 \%$ IT introduced & & 2013.1 & & & \\
\hline Kuroda easing & QE0, LSAP2 & 2013.4. & & & \\
\hline \multirow{2}{*}{\multicolumn{6}{|c|}{$\begin{array}{l}\text { Shaded cells indicate significance at the } 10 \% \text { level. } \\
\text { Other independent variables: S\&P } 500,10 \text { yr US treasury rate, JP }\end{array}$}} \\
\hline & & & & & \\
\hline US initial unemployment claims, The Dollar/Eur & ro rate. & & & & \\
\hline
\end{tabular}


Table 2A Regression Results Using Daily Data

\begin{tabular}{|l|l|}
\hline Upper House Dissolved & 2012.11 .16 \\
\hline LDP victory & 2012.12 .16 \\
\hline $2 \%$ IT introduced & 2013.1 .22 \\
\hline Kuroda easing & 2013.4 .4 \\
\hline Shaded cells indicate significance at the 10\% level. \\
\hline Other independent variables: S\&P500, 10 yr US treasury rate, the Dollar/Euro rate. \\
\hline Only the effects of the policy dummies during the Abenomics period are shown. \\
\hline
\end{tabular}

Table 3 Estimation results of the Soros equations

\begin{tabular}{|r|r|r|r|r|r|r|l|}
\hline & 10 Yr US Treas & Euro/Dollar r INSR & HJUS & HJ & HUS & SMPL \\
\hline 1 & 0.027 & 0.176 & 0.000227 & 0.21 & & & $1998.4-2013.4$ \\
& $(3.20)$ & $(2.38)$ & $(1.75)$ & $(3.36)$ & & & \\
\hline 2 & 0.0277 & 0.185 & 0.000245 & & 0.113 & -0.253 & $1998.4-2013.4$ \\
& $(3.24)$ & $(2.49)$ & $(1.88)$ & & $(1.12)$ & $(-3.52)$ & \\
\hline 3 & 0.0331 & 0.248 & 0.000197 & 0.113 & & & $1998.4-2008.8 \&$ \\
& $(3.74)$ & $(3.22)$ & $(1.43)$ & $(1.21)$ & & & $2009.3-2013.4$ \\
\hline 4 & 0.0337 & 0.246 & 0.000198 & & 0.0836 & -0.179 & $1998.4-2008.8 \&$ \\
& $(3.78)$ & $(3.19)$ & $(1.43)$ & & $(0.81)$ & $(-1.30)$ & $2009.3-2013.4$ \\
\hline
\end{tabular}

Notes: 1, INSR: US initial unemployment claims. HJ: monetary base (Japan). HUS: monetary base (US) HJUS=HJ/HUS.

2, The dependent variable is the Yen/Dollar exchange rate.

3, All variables are in log first differences except for the interest rate and INSR

which are in simple differences.

4. The equations also included a constant and the monetary policy dummies. 


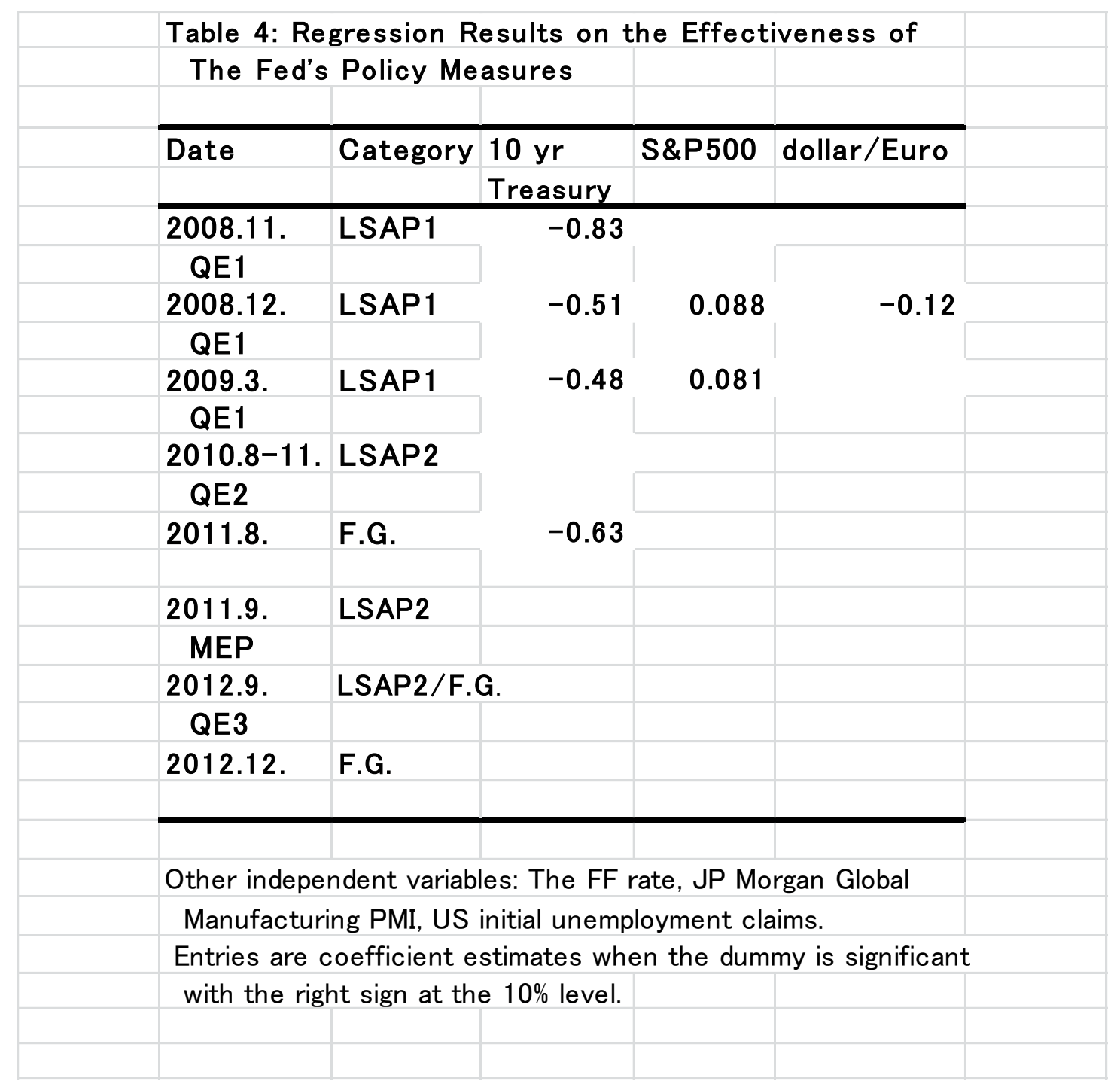



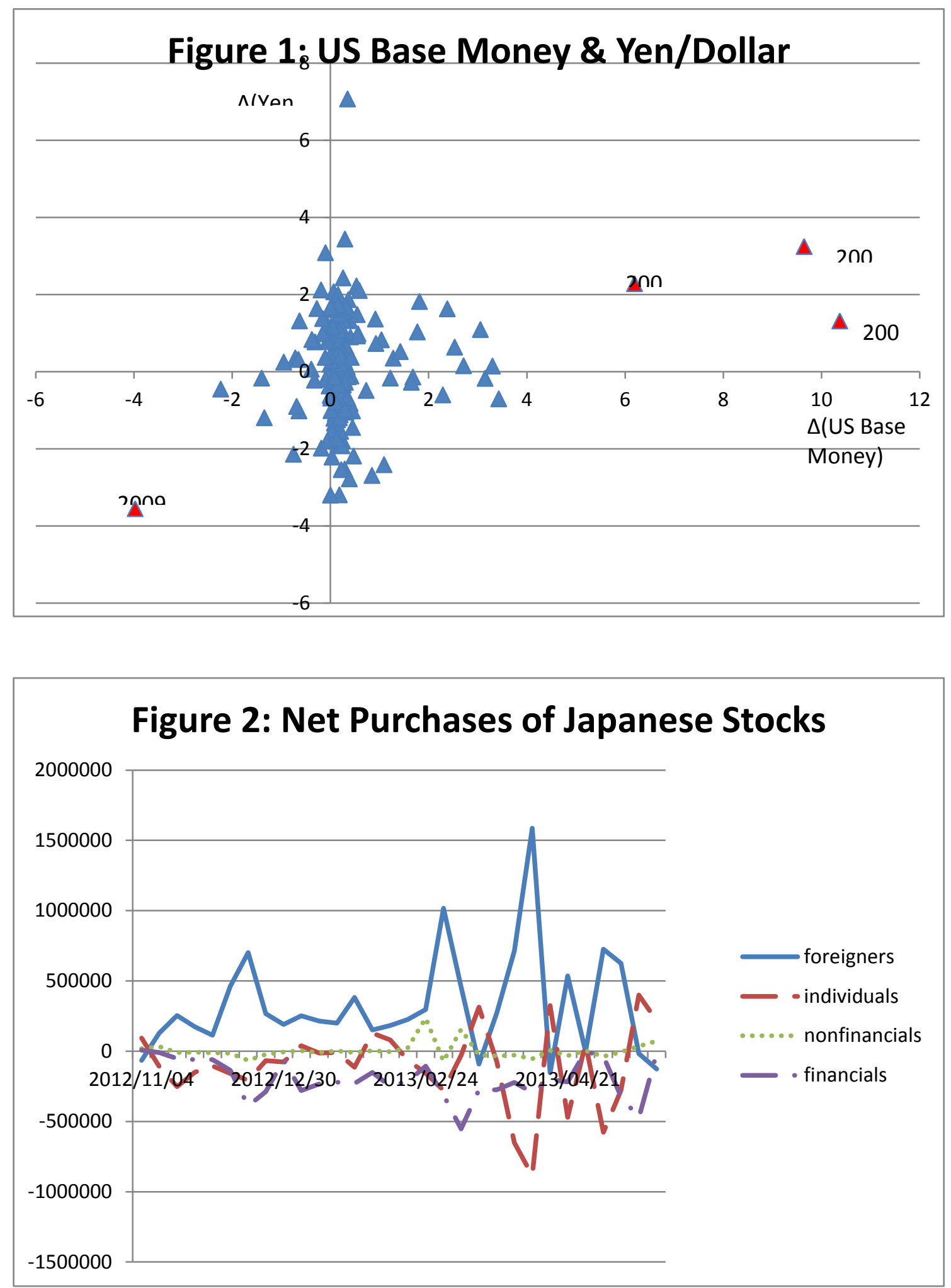